\title{
Use of Waste Materials to Improve Soil Fertility and Increase Crop Quality and Quantity
}

\author{
Giuseppe Corti, ${ }^{1}$ David C. Weindorf, ${ }^{2}$ Maria J. Fernández Sanjurjo, ${ }^{3}$ and Horea Cacovean ${ }^{4}$ \\ ${ }^{1}$ Dipartimento di Scienze Ambientali e delle Produzioni Vegetali, Università Politecnica delle Marche, Via Brecce Bianche, \\ 60131 Ancona, Italy \\ ${ }^{2}$ Louisiana State University Agricultural Center, 307 M.B. Sturgis Hall, Baton Rouge, LA 70803, USA \\ ${ }^{3}$ Departamento de Edafoloxía e Química Agrícola, Escola Politécnica Superior, Universidad de Santiago de Compostela, \\ Campus Universitario, Lugo, Spain \\ ${ }^{4}$ Oficiul Pentru Studii Pedologice si Agrochimice Cluj, Street Fagului 1, Cluj-Napoca, Judetul Cluj, Romania
}

Correspondence should be addressed to Giuseppe Corti, g.corti@univpm.it

Received 19 January 2012; Accepted 19 January 2012

Copyright ( $) 2012$ Giuseppe Corti et al. This is an open access article distributed under the Creative Commons Attribution License, which permits unrestricted use, distribution, and reproduction in any medium, provided the original work is properly cited.

The special issue received 21 papers from many countries. Of those, after a peer review, 13 were considered valuable for publication. Among the published papers, the use of broiler litter, stubble, mustard and flax meal cake, tannery land plaster, swine manure, and biosolids in cultivated soils was presented. Also, the use of compost to improve quality of urban soils, as well as inoculation of earthworms and application of biosolids and organic and inorganic residue to recover mine tails was included.

Specifically, S. L. Dillard et al. studied productivity and nutritive quality of Johnsongrass (Sorghum halepense) for forage after the soil had been treated with broiler litter and a commercial fertilizer made of ammonium nitrate and diammonium phosphate. Results indicated that broiler litter supported productivity and nutritive quality of the forage comparably to those obtained with commercial fertilizer when a supplement of $\mathrm{P}$ and $\mathrm{N}$ was applied.

G. B. Huang et al. assessed the role of stubble removal or retention and of soil management (no tillage and tillage consisting of 3 ploughing and 2 harrowing per year) on soil fertility in a loessic dryland cropping system dominated by alkaline soils mostly cultivated by wheat (Triticum aestivum L.) and pea (Pisum sativum L.). Other things being equal, after eight years of experimentation, the retention of stubble was able to improve the content of organic matter and the soil nutrient status and increase the grain yields too.
T. P. McGonigle et al. reported on the use of textile manufacturing wastewater sludge in greenhouse experiments using a silt loam soil, a gleyed melanic Brunisol according to the Canadian system of Soil Classification. The major focus of this paper is that sludge, even though not fragmented, may rapidly provide $\mathrm{N}$ in inorganic forms. Because of this, the use of sludge may substitute part of the $\mathrm{N}$ fertilizers needed for cereal cultivation.

Substituting fossil fuel cultivations generated the problem of eliminating meals and cakes derived from extraction of oil from seeds. A. S. Wang et al. considered the impact of biofuel oilseed meal application on some soil properties of a fine-silty, mixed, superactive, thermic Udifluventic Haplustept (USDA). The use of mustard and flax cakes may help in reducing fertilizer requirements, but there are also some risks derived from their use that are illustrated in the paper.

C. Giacometti et al. studied an animal-derived material, a by-product of leather shaving (TLP). Together with nutritive elements, this matter has a certain content of $\mathrm{Cr}$ (III), which may negatively impact soil biochemical properties. Using samples from a Typic Udifluvent (USDA), mesocosms were prepared with different amounts of TLP and incubated. Results indicated that TLP is a good source of available $\mathrm{N}$ and that extractable $\mathrm{Cr}$ (III) is rapidly reduced because of precipitation, but the effect of repeated applications must be further tested. 
In the paper of S. Amini et al., the effect of paper-mill sludge management on soil available nutrients and wheat grain production was tested. The authors worked on a loess soil from North-eastern Iran and evaluated the effect of the sludge used as mulching or incorporated into the soil by mechanical works. Results indicated that sludge mulching was able to improve physicochemical soil properties better than incorporation, and also yield production improved.

S. King et al. studied the very cogent matter of recycling swine manure. In this case the manure was submitted to an anaerobic digestion method known as ISPAD. The authors tested the validity of the ISPAD procedure in reducing ammonia volatilization versus conventional (untreated or stored in open tank) swine manure treatment when they are applied to soil. Manures were mixed to five experimental soil substrates and maintained into wind tunnels. Results indicated that the ISPAD procedure was able to reduce ammonia volatilization when manure is applied to soil and that plant available $\mathrm{N}$ is higher with respect to manure when conventionally treated.

A. A. Farooque et al. presented another particular treatment (the N-Viro) applied on sewage sludge disposal to produce biosolids used as fertilizers. In this paper the effect of these biosolids, together with irrigation, was evaluated on the availability of soil nutrients, plant nutrient uptake, and production of Vaccinium angustifolium growing on an Orthic HumoFerric Podzol. The results show that biosolids applied were comparable to the inorganic fertilizers used in the experiments.

R. E. Zartman et al. studied the effect of biosolids from waste-water treatment facilities on physical properties of fine, mixed, superactive, thermic Ustic Calciargids and loamy-skeletal, mixed, superactive thermic Ustic Haplocalcids submitted to artificial rainfall in order to improve vegetal cover and reduce erosion. The results obtained inform us that application of biosolids have achieved the goals and promoted the biosolids as environmental care product even for arid lands.

R. Pini et al. considered improving physical properties of poor quality urban soils with the application of compost derived from source-separated municipal solid waste so to increase the probability of success in establishing flowers. The soils used were those of traffic island, which were mainly made of reconstructed soil, and the plants used were wildflowers. After seven months from the compost application, the soils displayed improved physical conditions and also demonstrated a higher production of flowers for a longer time.

The paper of M. Rutheford and J. M. Arocena is one of the papers presented on the recovery of mine tailings. The aim was pursued working with materials from a Canadian non-acid mine tailing, which was amended with pulp sludge or pine sawdust plus biosolids, both enriched with earthworms of the species Dendrobaena veneta, an annelid. Results indicated that the addition of organics together with earthworms improved physicochemical properties of the mine tailing material that may favour plant establishment.

Also the paper of T. P. McGeehan concerns recovering mine tailings from Idaho (USA) by using seven waste-based and organic soil amendments in order to investigate the impact on soil-plant relationships. All the materials used improved soil fertility and were successful in establishing plant cover, even though biosolid products and waste log plus urea gave the best results.

Finally, the paper of C. Santibañez et al. is the third one to face the problem of recovering mine tailings. The work was made on tailings from a Chilean $\mathrm{Cu}$ mine. Several types of organic and mine waste materials were added to assess their efficacy on phytostabilization of the tailings. Results indicated that both hard-rock mine wastes and organic materials are adequate for improving chemical and biological properties of tailings, but excess of organic distribution must be avoided to prevent $\mathrm{Cu}$ mobilization.

All the results shown by the papers published in this issue are valuable for many viewpoints, including for law makers of any country, who may take the opportunity of this open issue to improve the environment and the economy of some farms where the materials here studied are produced or may be used.

Giuseppe Corti David C. Weindorf Maria J. Fernández Sanjurjo Horea Cacovean 

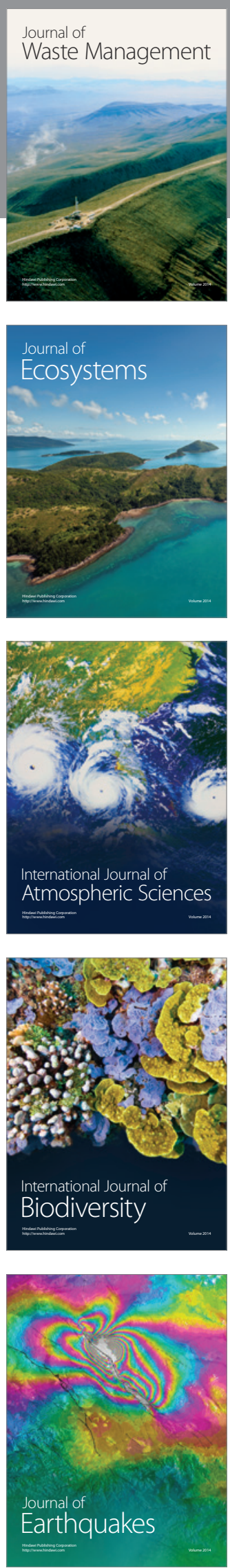
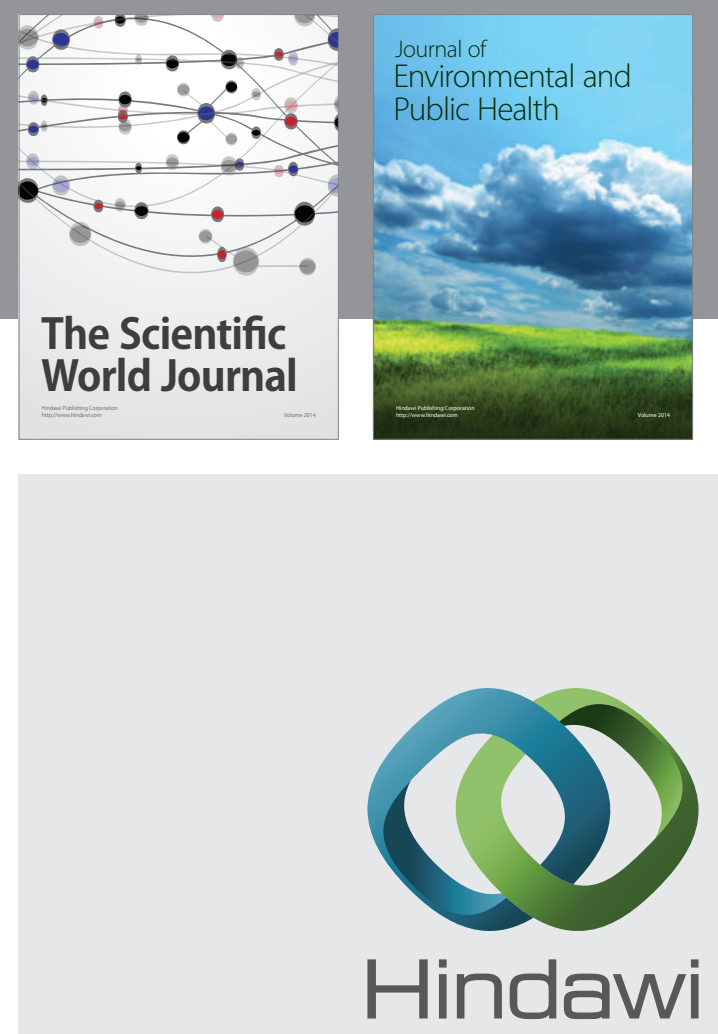

Submit your manuscripts at

http://www.hindawi.com
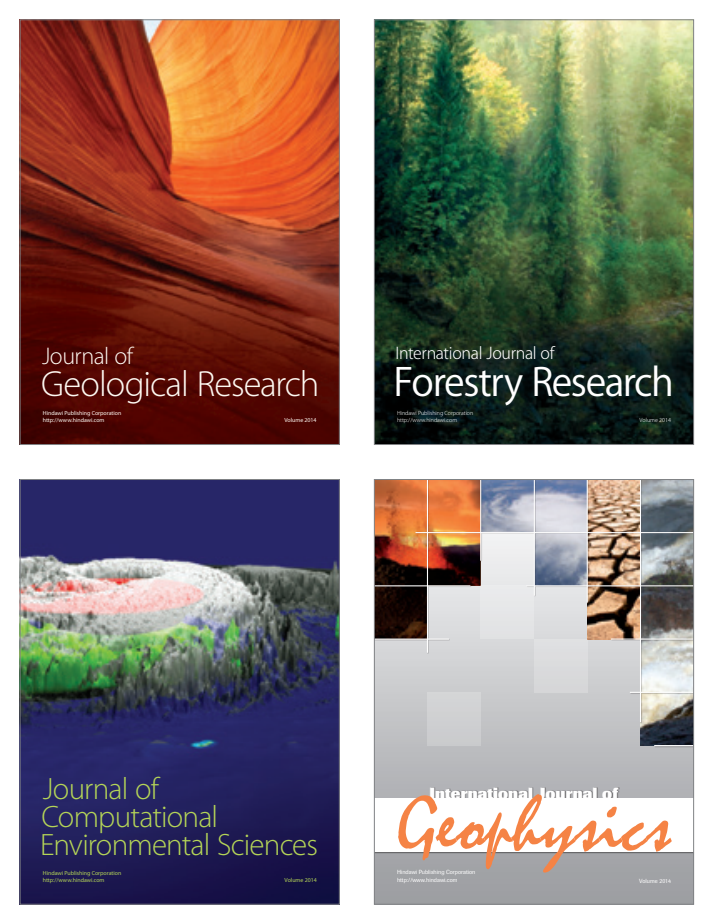
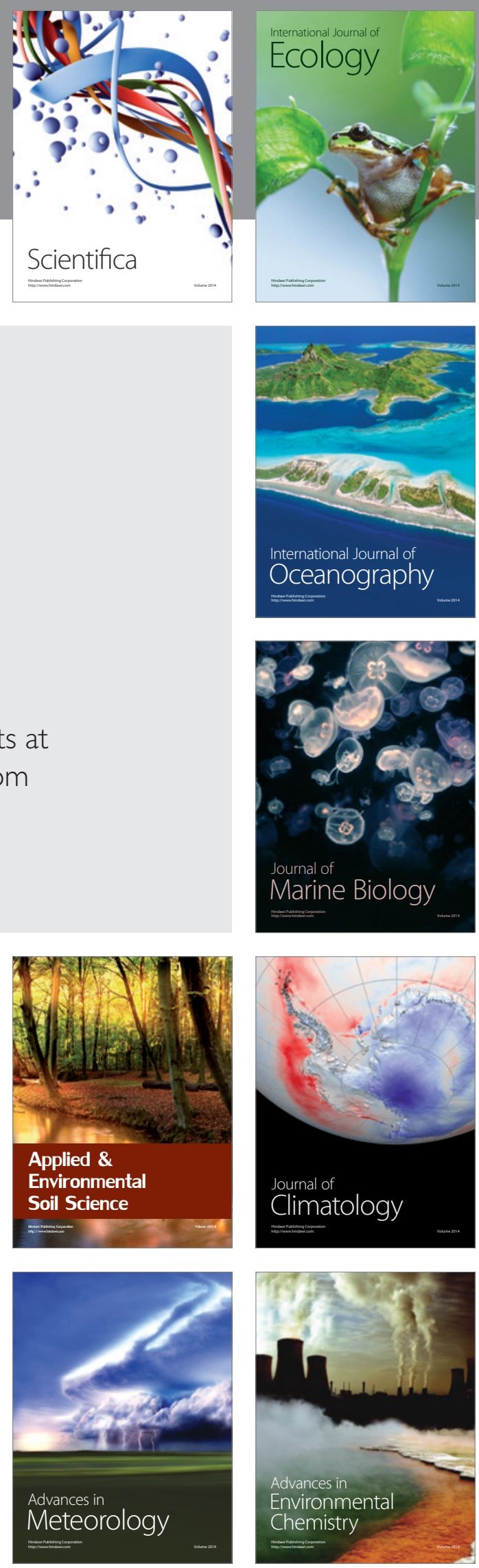